\title{
MARXISME EN ECOLOGIE: EEN UITGESTELDE ONTMOETING'
}

\author{
Matthias Lievens
}

Het marxisme heeft de ecologische kwestie gemist. Erg laat kwam een stroom aan publicaties op gang die deze benadering tracht te 'ecologiseren'. Zowel op het vlak van de theorie als dat van de praktijk leverde dit ondertussen een aantal aanzetten op voor een fundamenteel debat ter linkerzijde over de verhouding tussen maatschappij en ecosysteem, de private toe-eigening van de natuur, de aard van de technologie, de ecologische economie en strategieën voor alternatieven.

Het lijdt geen twijfel: het marxisme heeft grotendeels de ecologische kwestie gemist. Gedurende vele jaren werd niet meer dan lippendienst bewezen aan de strijd voor het milieu. Behalve enkele uitzonderingen heeft de milieubeweging zich de laatste veertig jaar ontwikkeld zonder noemenswaardig praktisch of theoretisch engagement van marxisten, van welke snit ook. Dat is op zich verrassend, als men de vergelijking maakt met de invloed en aantrekkingskracht die het marxisme uitoefende op het vlak van andere 'nieuwe' kwesties zoals het feminisme, holebibevrijding, de strijd van onderdrukte volkeren enzovoort. De hoeveelheid marxistische literatuur rond sommige van die thema's is onoverzienbaar.

Er kunnen verschillende hypothesen geformuleerd worden om deze situatie te begrijpen. Vooreerst op politiek vlak: toen de nieuwe linkse generatie van de jaren '60 en '70 dacht dat de revolutie kon triomferen in Europa, leken de milieueisen te partieel, onmiddellijk en secundair tegenover de cruciale sociale strijd. Toen dat mateloze optimisme begon te wijken, en het erop aan kwam stand te houden tegen de neoliberale golf vanaf eind jaren '70, leek de ecologische crisis steeds meer een globaal probleem dat enkel via een fundamentele maatschappijverandering opgelost zou kunnen worden. Telkens hielden marxisten er een te enge opvatting op na over sociale strijd. ${ }^{2}$ Hun strategisch kader vertrok van de emancipatorische verzuchtingen van allerlei onderdrukte groepen, zonder veel oog te hebben voor het feit dat niet enkel groepen mensen de gevolgen dragen van de huidige maatschappij, maar ook de natuur.

Ook in de theorie en de maatschappijanalyse mangelde er wat. Het meest kritische en creatieve Europese marxisme van de eerst helft van de twintigste eeuw, dat van onder andere Gramsci, Lukács en Korsch (die later grote invloed zouden uitoefenen op de Frankfurter Schule) ontbeerde elk begrip van de natuur. 
Op een aantal uitzonderingen na (bijvoorbeeld Barry Commoner, Rudolf Bahro...) hebben weinig $20^{\text {ste- }}$ eeuwse marxisten dan ook kaas gegeten van de milieukwestie. Uiteraard hebben we het hier dan nog niet over het zogenaamde 'reëel (on)bestaande socialisme' van het Oostblok, dat sommige van de grootste milieurampen op zijn naam kan schrijven.

Onder ecologisten bestaat dan ook een begrijpelijke kritische distantie tegenover een denkstroming die weinig lijkt te kunnen bijdragen aan de dringende ecologische strijd. De beperkingen van het marxisme worden door sommigen teruggevoerd op het vermeende productivisme en prometheïsche vooruitgangsgeloof van de grondleggers ervan. Ook voor hen geldt dat Marx dood is, zoals zovelen meenden na 1989. Het aantal doodverklaringen van Marx is niet meer te tellen, en dat is toch een beetje verdacht, stelde Jacques Derrida in zijn fascinerende boek Spectres de Marx uit $1993 .{ }^{3}$ Marx mag dan al dood zijn, zijn spoken blijken steeds weer te worden opgeroepen. En dat is niet toevallig: zolang het kapitalisme sociale onrechtvaardigheid creëert, zal dat zo blijven. Wie zich vandaag echter op Marx wil beroepen, meent Derrida, moet erkennen dat er vele geesten van Marx zijn, en dat we selectief en creatief moeten zijn in de omgang met deze 'erfenis'. Met zo'n erfenis kun je niet renterieren. Er is niet één marxisme, één systeem: het marxisme is een lappendeken van concepten, theorieën, praktijken en ervaringen. Sinds een tiental jaar is er éen zwakke, maar reële draad in dat lappendeken die steeds meer aandacht krijgt: die van de ecologisering van het marxisme. Een gestaag toenemende stroom aan publicaties voedt een internationaal debat dat steeds boeiender wordt. Dit debat heeft een evidente bestaansreden: het is niet toevallig dat de eerste tekenen van de milieucrisis die we vandaag kennen de kop opstaken toen ook de maatschappijvorm ontstond die het marxisme tracht te begrijpen: de kapitalistische productiewijze.

Tegelijk engageren steeds meer marxistisch geïnspireerde organisaties zich ten volle in de ecologische strijd (rond klimaat, tegen genetische manipulatie enzovoort). Vandaar het belang om binnen de ecologische beweging, als eenheid van verschillende stromingen, ook het theoretische debat te voeren over de bijdragen die verschillende van die denkstromingen kunnen leveren. In wat volgt bespreek ik de pogingen om het marxisme te 'ecologiseren' en de limieten hiervan. Vervolgens komen een aantal belangrijke actuele debatten aan bod, zoals de discussie met de ecologische economie, en die over ecosocialisme.

\section{Een breuk in het metabolisme}

De inzet van het debat over marxisme en ecologie kan voor marxisten enkel bescheiden zijn. Het komt er niet op aan de ecologie te 'marxiseren', maar wel 
het marxisme te 'ecologiseren'. Dat was ook het opzet van John Bellamy Foster, hoofdredacteur van het Amerikaanse tijdschrift Monthly Review, toen die in de jaren ' 90 werkte aan een boek over 'Marx en ecologie'. Zijn aanvankelijke bedoeling om de ecologische hiaten in Marx' theorie op te sporen en te corrigeren, stuurde hij gaandeweg bij. De titel van zijn boek Marx's Ecology bevat dan ook de boude, door sommige marxisten gecontesteerde, ${ }^{4}$ stelling dat in Marx wel degelijk de grondslagen te vinden zijn voor een ecologische theorie. ${ }^{5}$ Verschillende elementen passeren in zijn boek de revue: Marx' materialisme (mensen zijn deel van de omvattende materie of natuur), zijn interesse voor Darwin, de polemiek met Malthus. Wat van dit boek echter een mijlpaal maakt in de ontwikkeling van een ecologisch marxisme, is de analyse van het sleutelbegrip van het metabolisme tussen mens (of maatschappij) en natuur, en van wat Marx de 'metabolische breuk' noemde. Deze vergeten begrippen, die zich in het hart van Marx' maatschappijdiagnose bevinden, vormen volgens Foster een vruchtbare voedingsbodem voor een beter begrip van de milieucrisis vanuit een marxistisch kader, dit wil zeggen voor de poging om de theoretische analyse van de kapitalistische productiewijze opnieuw te verbinden met haar natuurlijke bestaansvoorwaarden.

Het begrip metabolisme (Stoffwechsel), dat ook vandaag cruciaal is in de ecologische discussie, werd rond 1815 geïntroduceerd door fysiologen, die ermee verwezen naar de materiële uitwisselingen binnen het lichaam. De bekende Duitse chemicus Justus von Liebig (1803-1873) verruimde het begrip tot een geheel van natuurlijke cycli. Het staat onder andere centraal in zijn vernietigende kritiek van de Britse landbouw. Liebig analyseerde hoe irrationele landbouwmethodes in Groot-Brittanië in de $19^{\text {de }}$ eeuw de bodem uitputten. Heel simpel gesteld: de voedingsstoffen die de landbouwgewassen bevatten, werden geconsumeerd in de stad (Londen), zonder dat ze terug in de bodem terecht konden komen. De bodem geraakte uitgeput, de Thames vervuild. De natuurlijke cyclus werd onherstelbaar doorbroken. De enige manier om dit te compenseren was door bodemnutriënten te importeren van elders: in de jaren 1840 werden bijvoorbeeld honderdduizenden ton guano uit Pen naar Engeland getransporteerd. Daardoor werd het doorbreken van de natuurlijke cycli een fenomeen met wereldwijde omvang, dat zich niet enkel tussen stad en platteland afspeelde, maar ook tussen noord en zuid.

Tijdens zijn studie voor Het Kapitaal had Marx ook auteurs als Liebig gelezen, en er vergaande conclusies uit getrokken. Hij pikte de concrete analyses van de chemicus op, om er de basis van een algemenere diagnose van te maken. De "destructieve kant van de moderne landbouw" heeft volgens hem het metabolisme tussen mens en natuur onherstelbaar verstoord. De kapitalistische productie "vernietigt (...) de stofwisseling tussen mens en aarde", ${ }^{6}$ die nochtans voortvloeit uit de natuurlijke wetten van het leven zelf." "Iedere vooruitgang in de kapitalistische landbouw is niet alleen een vooruitgang in de kunst arbeiders 
te beroven, maar tevens in de kunst van roof op de grond; iedere vooruitgang in het vergroten van de vruchtbaarheid van de grond voor een bepaalde periode, is tevens een vooruitgang in het vernietigen van de blijvende bronnen van deze vruchtbaarheid. Naarmate een land zich voor zijn ontwikkeling meer baseert op de grootindustrie (zoals bijvoorbeeld de Verenigde Staten) des te sneller werkt dit vernietigingsproces." ${ }^{98}$ De gelijktijdige groei van grootschalige industrie en landbouw ligt aan de basis van wat Marx in een aantal van zijn meest wetenschappelijke - en minst gelezen - teksten de 'breuk' in het metabolisme is gaan noemen. Het metabolisme is volgens hem het proces van materiële uitwisseling tussen mens en natuur zoals dat in elke vorm van productie plaatsvindt, niet enkel in individuele arbeidsprocessen, maar ook op het vlak van het economische systeem in zijn totaliteit. In bepaalde vormen van productie geraken de economische cyclus en de cyclus van de natuur echter in onevenwicht. Het kapitalisme maakt van dit proces van stofwisseling voor het eerst een globaal, wereldomspannend gebeuren, maar verstoort het tegelijk diepgaand. ${ }^{9}$

De mechanismen die het kapitalisme in gang zet om hieraan het hoofd te bieden, vergroten het probleem alleen maar: de commercialisering van de voortbrengselen van de grond en de handel op lange afstand reproduceren het probleem op globale schaal. Het loutere feit dat zaden, meststoffen en andere natuurlijke producten moesten worden ingevoerd, toonde volgens Marx al aan dat de kapitalistische landbouw niet langer zelfvoorzienend was, maar dat de natuurlijke voorwaarden ervan een industrie op zich zijn geworden, die enkel aan commerciële imperatieven beantwoordt. ${ }^{10}$ Ondanks alle wetenschappelijke inzichten bleek het kapitalisme volgens Marx niet in staat om de rijkdom van de bodem in stand te houden. Een cruciale opdracht voor de opbouw van een alternatief maatschappijmodel zal er dan ook in bestaan dat "de geassocieerde producenten het menselijk metabolisme met de natuur op een rationele wijze gaan besturen". "1!

Het kapitalisme tracht eigenlijk het onmogelijke te doen: zich te onttrekken aan de menselijke afhankelijkheid van de natuur, door van die natuur private eigendom te maken:

"Vanuit het standpunt van een hogere economische maatschappijvorm zal de private eigendom van de aarde even absurd lijken als de private eigendom van één mens door een ander. Zelfs een hele maatschappij, een natie, of zelfs alle tegelijk bestaande maatschappijen samen zijn niet de eigenaars van de aarde. Ze zijn enkel de bezitters ervan, de vruchtgebruikers, en moeten deze als boni patres familias in een verbeterde conditie doorgeven aan toekomstige generaties." 12 


\section{Onteigening van de commons}

De breuk tussen de menselijke activiteit en zijn anorganische, natuurlijke condities, die pas volledig wordt binnen de kapitalistische productiewijze, is volgens Marx het gevolg van een historisch proces, en moet ook zo verklaard worden. ${ }^{13}$ Paul Burkett, een andere pionier van het ecomarxisme, toont hoe deze breuk voortvloeit uit een proces dat een aantal eeuwen duurde, en uiteindelijk vanaf eind $18^{\text {de }}$ eeuw de ontwikkeling van de kapitalistische productiewijze mogelijk maakte. ${ }^{14}$ Dit proces is wat Marx in abstracte termen 'de scheiding van de producenten ten opzichte van de productievoorwaarden' noemde (en in zijn vroege werk onder de noemer van de 'vervreemding' geanalyseerd werd ${ }^{15}$ ). Vaak worden de productievoorwaarden te eng gedefinieerd, louter in termen van eigendomsverhoudingen. Voor Marx gaat het hier echter niet enkel om een scheiding van de arbeiders ten opzichte van de productiemiddelen, die privébezit worden, maar ook ten opzichte van de natuurlijke voorwaarden van het productieproces.

Volgens Marx ontstond het kapitalisme op basis van 'primitieve accumulatie': de roof van bestaande rijkdommen en de plundering van de commons. Het gaat hier om een historisch proces dat in Engeland bijvoorbeeld gestalte kreeg in de enclosures: gemeenschappelijke gronden werden toegeëigend door grootgrondbezitters, en kleine lokale boeren werden gedwongen naar de stad te trekken als loonarbeiders. Die private inbezitneming van de commons lag aan de basis van verschillende fenomenen: het ontstaan van grootschalige kapitalistische landbouw, de verscherping van de tegenstelling tussen stad en platteland (en vervolgens tussen noord en zuid), en het ontstaan van de moderne klassen van burgerij en proletariaat.

Terwijl boeren voorheen op kleine schaal werkten, gebonden aan hun ecologische niche, gaat het beginnend kapitalisme dit openbreken: arbeidskracht, grond en arbeidsinstrumenten worden uiteengetrokken en komen als koopwaar op de markt tegenover mekaar te staan. Op die manier wordt de kapitalistische productiewijze de eerste in de geschiedenis waarin de economie als het ware een eigenstandig domein wordt met specifieke wetmatigheden, die door een aparte economische wetenschap onderzocht worden. Voorheen was de productie ingebed in een religieus, politiek en ecologisch geheel, nu ontwikkelt het kapitalisme zich los daarvan, op een quasi-blinde manier. Dat levert een aantal mechanismen op die ecologisch destructief zijn. Er ontstaat een steeds groeiende kloof tussen de enorme kapitaalsaccumulatie en de steeds snellere cycli van het kapitaal enerzijds, en de grenzen van de aarde en de tragere cycli van het ecosysteem anderzijds. ${ }^{16}$ Het kapitaal dringt steeds verder door in alle domeinen van het menselijk leven, creëert voortdurend nieuwe behoeften, en transformeert alles tot ruilwaarde. De terugkerende overproductiecrisissen gaan gepaard met massale vernietiging van goederen en kapitaal. De doorgedreven rationaliteit die 
individuele kapitalistische bedrijven aanwenden in het 'wetenschappelijk management' om zoveel mogelijk winst te maken, staat in contrast met de globale irrationaliteit van het systeem, dat geen rekening houdt met menselijke of natuurlijke noden. ${ }^{17}$ Dat er een duidelijke band is tussen de ontwikkeling van het kapitalisme en de ecologische catastrofe, betekent niet dat er in prekapitalistische maatschappijen geen milieucrises waren. Deze bleven echter doorgaans lokaal beperkt (bijvoorbeeld uitputting van de bodem, afbranden van bossen...). Met de intrede van de globale systeemlogica van het kapitalisme is de milieucrisis echter eveneens globaal geworden.

Ondanks zijn poging los te komen van het ecosysteem, blijft de kapitalistische economie uiteraard fundamenteel afhankelijk van de natuur. De scheiding van economie en natuur leidt dan ook tot de roofbouw op deze laatste. Dat is de kern van Marx' theorie van de metabolische breuk. Ook al is die theorie onaf, haar belang is reëel: ze toont immers dat de milieucrisis geen crisis is van de natuur, maar van de maatschappij, meer bepaald van de relatie die de maatschappij sinds een goeie tweehonderd jaar aangaat met haar natuurlijke voorwaarden. Ze laat zien hoe de sociale en ecologische kwestie fundamenteel verbonden zijn: het historische proces dat de moderne kloof tussen arm en rijk voortbracht is ook het proces dat de kloof tussen mens en natuur creëerde. Zowel arbeid als natuur zijn bronnen van rijkdom, ${ }^{18}$ en beide geraken uitgeput door de kapitalistische accumulatie.

Maatschappij en natuur verschijnen in het kapitalisme als aparte entiteiten, maar kunnen eigenlijk niet gescheiden worden. Dat is wat een wetenschappelijke analyse moet aantonen. Op basis van een dergelijk metabolisch perspectief moet het ook mogelijk worden om te laten zien hoe elk sociaal fenomeen, elke sociale verhouding, elke sociale crisis steeds een bepaalde verhouding tot de natuur impliceert. ${ }^{19}$

Daarmee mag niet gezegd zijn dat de ecologische kwestie te reduceren valt tot een sociale kwestie. Er bestaat immers belangrijke ecologische strijd, bijvoorbeeld voor biodiversiteit, die niet onmiddellijk een sociale strijd is: de ecologische kwestie en dito strijd hebben dan ook hun zelfstandigheid. Er is een ecologisch bewustzijn dat niet gereduceerd kan worden tot een sociaal (klassen)bewustzijn, maar in alle lagen van de bevolking op één of andere manier aanwezig kan zijn. De oplossing van de sociale kwestie (socialisme) is bijgevolg ook niet voldoende om ook de ecologische kwestie op te lossen (vandaar de noodzaak om te denken in termen van ecosocialisme, zie verder). Wel is duidelijk dat een andere verhouding van de maatschappij tot de natuur een andere maatschappijstructuur veronderstelt, die het mogelijk maakt de scheiding tussen producenten en productievoorwaarden zoveel mogelijk op te heffen. Het milieuprobleem kan dan ook niet beperkt worden tot een probleem van 
individueel keuzegedrag binnen het bestaande kader (liberalisme) noch van het aantal mensen op deze planeet (malthusianisme). Deze beide factoren zijn precies onlosmakelijk verbonden met de functioneringswijze van de maatschappij. Liberalisme en malthusianisme blijven blind voor de maatschappijstructuur en de wijze waarop deze met de natuur verbonden is. Ze focussen eenzijdig op individuele keuzes of zien de maatschappij louter als de optelsom van individueel gedrag. In hun praktisch-politieke conclusies laten ze de maatschappijstructuur dan ook ongemoeid.

\section{Tragedie}

Uiteraard ging het openbreken van traditionele, op de gemeenschap gebaseerde productievormen en de private toe-eigening (of vervreemding) van de commons door de bezittende klasse gepaard met massaal volks verzet. Tegen de privatisering van de bossen bijvoorbeeld (die eigenlijk het opstapje vormt naar de privatisering van andere energiebronnen zoals steenkool en olie) bestonden massale verzetsbewegingen. Het is geen toeval dat de jonge Marx zich in én van zijn eerste artikelen keerde tegen de veroordeling van wie hout sprokkelde in wat vroeger gemeenschappelijke wouden waren.

Garrett Hardin's stelde in zijn Tragedy of the Commons dat de commons onherroepelijk leeggeroofd zullen worden door freeriders zolang niet duidelijk is wie de verantwoordelijke eigenaar is. De échte tragedy of the commons lijkt echter voort te vloeien uit hun private toe-eigening, en de grootschalige landbouw in monocultuur die daar historisch op volgde. Het is pas de armoede die het gevolg is van het privé-bezit die aan de basis lag van de latere roof van de wouden door het gewone volk.

Het bewustzijn van het probleem van de commons was ook aanwezig in de volkse strijd tegen de privatisering. In de Duitse boerenoorlog van de $16^{\text {de }}$ eeuw bijvoorbeeld, die Engels analyseerde als een begin van de moderne klassenstrijd, werden door de volksbeweging bijvoorbeeld eisen naar voor geschoven voor een verkozen commissie die de gemene bossen zou moeten beschermen, om de privatisering of roof ervan tegen te houden. ${ }^{20}$

Dit proces van de onteigening van de commons en de voortschrijdende omvorming van prekapitalistische in kapitalistische relaties gaat vandaag onverminderd voort. In landen als China, India of Brazilië trokken de laatste twintig jaar tientallen miljoenen mensen weg van het platteland, onder andere verjaagd door de concentratie van het privé-bezit, om in de stad als loonarbeider te werken. Vandaag tracht men voor de klimaatcrisis een oplossing te vinden die compatibel is met het privé-bezit, en eigenlijk de privatisering van de commons verder uitdiept: zelfs de lucht wordt vandaag een quasi-privaat goed via de handel in emissierechten binnen het kader van Kyoto. ${ }^{21}$ 


\section{Grenzen van de natuur}

Er wordt wel eens gesteld dat Marx een technologisch optimist was, die een grenzeloos vertrouwen had in de ontwikkeling van de 'productiekrachten' (dit wil zeggen alle krachten die door mensen ingezet worden in het productieproces). Dergelijke interpretaties kunnen ongetwijfeld steunen op een aantal uitspraken van Marx die erg productivistisch zijn, en simpelweg verworpen, moeten worden. Het is inderdaad zo dat een term zoals 'productiekrachten' erg vaag is, en te weinig toelaat het onderscheid te maken tussen duurzame en onduurzame, bevrijdende en onderdrukkende vormen van bijvoorbeeld technologie. ${ }^{22}$

Marx verbindt weliswaar de groei van de productiekrachten met 'de veelzijdige ontwikkeling van het individu': productiekrachten omvatten veel meer dan louter technologie. Hij toont ook aan hoe technologie niet sociaal (en ecologisch) neutraal is. Toch zijn er een aantal passages waarin Marx hier weinig rekenschap van geeft. De Belgische marxist Ernest Mandel stelde dat de 'productiekrachten' meer en meer 'destructiekrachten' worden, maar ook hij leverde niet de instrumenten om dat preciezer te analyseren.

Een daarmee verbonden kwestie, waar critici op wijzen, is dat Marx geen notie zou hebben van de grenzen van de natuur. Als $19^{\text {de }}$-eeuwer kan Marx natuurlijk bezwaarlijk een ecologist genoemd worden. Toch is een sleutelstuk van zijn economische theorie, de leer van de grondrente, gegrondvest in de gedachte dat de aarde begrensd is. Marx stelt vast dat de landbouwprijzen op de markt bepaald worden door de productiekosten op de minst vruchtbare akkers. Dat betekent dat wie op vruchtbaarder grond werkt, en dus efficiënter produceert, een surpluswinst kan binnenrijven (met als gevolg dat het erop aankomt de grond op korte termijn 'productiever' te maken aan de hand van pesticiden, machines, genetisch gemanipuleerde zaden enzovoort, om zoveel mogelijk dergelijke surpluswinst te kunnen binnenrijven). Als er geen grenzen waren aan de aarde, zou die rente onmogelijk worden, en de drang om zoveel mogelijk natuurlijke grondstoffen privaat toe te eigenen, zou uiteraard volstrekt overbodig worden. Het is op basis van de grenzen van de natuur, dat degenen die deze privaat toe-eigenen hun condities kunnen opleggen aan de rest van de bevolking.

Daniel Tanuro, één van de enige Belgische marxisten die in dit debat oorspronkelijke bijdragen leverde, heeft aangetoond dat het niet op dit punt is dat Marx' ecologie gebreken vertoont. ${ }^{23}$ Marx ging wel degelijk uit van de grenzen van de aarde, en toonde hoe de privatisering van de commons aan de basis ligt van de metabolische breuk. Vervolgens liet hij zien hoe op de toe-eigening van de bossen en de grond die van de mijnen volgde (en op de grondrente een mijnrente). De beschikbare voorraden steenkool, en later aardgas en -olie, werden zo privaat eigendom, en leveren enorme rentes op. ${ }^{24}$ Het gaat hier om big 
business: de petroleumrente bedraagt vandaag een slordige 1000 tot 1500 miljard euro per jaar. Dat is de volledige winst van de mondiale petroleumsector. ${ }^{25}$

Het probleem is echter dat Marx die voortschrijdende private toe-eigening als een continu proces leek te beschouwen. Hij zag volgens Tanuro niet dat er een fundamentele breuk bestaat tussen het kapitalistische gebruik van hout (en andere gelijkaardige voortbrengselen van de natuur) als energiebron, en dat van steenkool: het is het verschil tussen energie als stroom en als stock, en dus tussen potentieel hernieuwbare en uitputbare energiebronnen. Het is mogelijk de kapitalistische uitpulting van hout bij te sturen door een 'rationele regulatie van het metabolisme': binnen een zekere cyclus kan een woud opnieuw aangroeien (hoewel het maagdelijk oerwoud natuurlijk nauwelijks hersteld kan worden). De voorraad steenkool, gas en olie geraakt echter onherroepelijk uitgeput, en het klimaat onherstelbaar aangetast.

Dat heeft verregaande gevolgen. Marx suggereerde nog dat het kapitalisme de condities zou creëren voor een hogere, socialistische maatschappijvorm. Het kwam eropaan het metabolisme dat onder het kapitalisme verstoord is geraakt, te reguleren door de rede in plaats van dit over te laten aan de blinde kapitaalwetten. Vandaag weten we echter dat het stoppen van de kapitalistische accumulatiemachine en het herstel van het metabolisme niet enkel 'bijsturingen' zal vergen aan de wijze waarop de huidige economie omgaat met de natuur. Een duurzame maatschappij zal fundamenteel het energiesysteem en de technologie waarop ze is gebaseerd, moeten omwentelen. Een 'rationele regulatie van het metabolisme' is simpelweg niet mogelijk op basis van uitputbare energiebronnen. De 'groei van (de kapitalistische) productiekrachten' creëert dan ook niet de basis voor een 'rationele regulatie van het metabolisme' onder het socialisme, maar ondermijnt veeleer de mogelijkheid van een duurzame maatschappij. Vandaar dat de transformatie van het kapitalisme naar een andere, duurzame maatschappijvorm veel diepgaander zal moeten zijn dan enkel de verandering van de eigendomsverhoudingen. Daarover straks meer.

\section{Ecologische economie}

Ecomarxisten menen dus goede redenen te hebben om te stellen dat het mogelijk is de marxistische theorie te reconstrueren op basis van een analyse van het metabolisme tussen mens/maatschappij en natuur. Volgens Paul Burkett plaatst dit het marxisme in het kamp van de ecologische economie. Deze tak in het economisch denken over ecologie ontstond vrij recent vanuit een oppositie tegen de dominante milieueconomie. ${ }^{26} \mathrm{Het}$ uitgangspunt van de ecologische economie is eigenlijk vrij helder: de aarde is begrensd, en dus moet de doorstroom van materie en energie uit de aarde in de economie (en terug) ook begrensd worden. Ecologische economen als Herman Daly meenden lang dat het marxisme buiten 
hun veld viel en hier geen enkele bijdrage aan kon leveren: het marxisme zou een notie van de grenzen van de natuur ontberen, en niet compatibel zijn met de wetten van de thermodynamica. In zijn boek Marxism and Ecological Economics. Towards a Red and Green Political Economy tracht Burkett deze kritieken te weerleggen en argumenteert hij dat marxisten en ecologische economen fundamenteel aan het zelfde zeel trekken.

Burkett gaat omstandig in op een aantal controversen binnen het veld van de ecologische economie. Hij tracht deze vooral te ontdoen van een aantal onhoudbare liberale denkwijzen die er zijn binnengeslopen. Zo gaat hij in op de controverse over de waarde (en dus de prijs), en bekritiseert sommige ecologische economen die een biofysische of bio-energetische theorie van de waarde voorstaan. Door van de prijs een uitdrukking te maken van energiestromen in de natuur dreigen zij van de prijs (en dus van de markt) iets te maken dat inherent is aan de natuur, terwijl de markt eigenlijk pas ontstaan is door een historisch proces van toenemende vervreemding ten opzichte van de natuur. Het begrip 'natuurlijk kapitaal' dat sommige ecologische economen hanteren, is in hetzelfde bedje ziek.

Zolang mensen leven van de gebruikswaarden die ze in de natuur vinden of zelf voortbrengen, bestaan er geen prijzen of markten. Het feit dat de natuur een prijs krijgt en dus geprivatiseerd wordt, toont hoezeer mensen al vervreemd zijn geraakt van de communale voorwaarden van het maatschappelijke bestaan, en hoe ze tegenover de natuur als tegenover een koopwaar komen te staan. Het is de logica van die koopwaar en het geld, die mee de deur opende voor de milieucatastrofe: geld is opdeelbaar, perfect mobiel en onbeperkt accumuleerbaar terwijl de natuur dat niet is. Het is niet toevallig dat de eigenschappen van fossiele brandstoffen goed gelijken op die van geld: deze brandstoffen maken het mogelijk te produceren waar (ongeacht de lokale ecologische condities) en wanneer (24 uur op 24) men maar wil. ${ }^{27}$

Burkett benadrukt dat de strijd tegen de geldlogica zowel een sociale als ecologische strijd is. Voor de natuur zowel als voor de arbeiders is het niet de prijs (de ruilwaarde) van goederen die van belang is, maar wel de gebruikswaarde. Telkens moet een strijd gevoerd worden tegen kwantificatie en tegen het abstractie maken van concrete menselijke en ecologische noden.

Het belangrijkste punt van controverse binnen de ecologische economie is natuurlijk dat van de alternatieven. Herman Daly pleit voor quota voor de extractie van grondstoffen uit de natuur en voor menselijke voortplanting. Het probleem met het marktmechanisme, aldus Daly, is niet dat het de beschikbare grondstoffen op een onecologische manier zou distribueren (allocatie), maar dat het blind is voor het probleem van schaarste en schaal. Vandaar dat volgens hem een collectieve beslissing de schaal van de economie moet beperken. Binnen dat kader kan de markt vervolgens voor optimale allocatie zorgen. 
De vraag is echter of het probleem van de schaal en dat van de allocatie zo gemakkelijk gescheiden kunnen worden. Burkett wijst erop dat de markt zoals die vandaag bestaat, onvermijdelijk leidt tot schaalvergroting. Uiteraard is er een onderscheid tussen de markt enerzijds en het kapitalisme anderzijds: de markt bestond al duizenden jaren voor het kapitalisme eind $18^{\text {de }}$ eeuw ontstond, en zal ongetwijfeld ook in postkapitalistische samenlevingen nog een tijdlang een rol spelen. Wat de kapitalistische productiewijze in gang zette, was het ontstaan van twee specifieke markten: die van de koopwaar arbeidskracht, en die van de productiemiddelen. Voor de ecologische economie is het van het grootste belang in te zien dat waar deze twee markten bestaan, economische groei onvermijdelijk is, en het handhaven van een maximale schaal van de economie onmogelijk. Een kapitalist investeert immers maar om winst te maken, dit wil zeggen kapitaal te accumuleren, en dus economische groei te realiseren. Uiteraard moet elke kapitalist efficiënter trachten te produceren dan zijn concurrenten, wat onder andere kan betekenen dat de doorstroom van materie en energie per eenheid product wat kleiner wordt. Maar dit gaat wel steeds gepaard met een toename van de totale hoeveelheid producten, en dus met een meer dan waarschijnlijke stijging van de globale doorstroom. Economische groei gaat nagenoeg altijd gepaard met een hogere doorstroom. In vaktaal luidt het dat de entropie van het kapitalisme haaks staat op de entropische vereisten van duurzame ontwikkeling. Het noodzakelijke stilleggen van de groei of de inkrimping van de materiële economie zijn eenvoudigweg onmogelijk binnen een kapitalistisch kader. Wie dat wel wil proberen, zal onvermijdelijk uitkomen bij een pleidooi voor een 'sterke staat' met een enorm controleapparaat om alle bedrijven en consumenten aan hun opgelegde quota te houden, terwijl deze laatste er door de marktlogica zelf alle belang bij hebben om die quota niet te respecteren.

Die contradictie tussen kapitalistische groei en de noden van het ecosysteem leidt natuurlijk tot crisisfenomenen. Volgens Paul Burkett moet een onderscheid gemaakt worden tussen twee types van crisis. Enerzijds zijn er de ecologische crises die de kapitaalsaccumulatie in het gedrang dreigen te brengen, bv. door de uitputting van belangrijke grondstoffen. Anderzijds is er de door het kapitalisme veroorzaakte crisis van het ecosysteem en van de voorwaarden voor duurzame menselijke ontwikkeling als zodanig, zoals de klimaatswijziging of het biodiversiteitsverlies. ${ }^{28}$

Het probleem is nu dat die tweede vorm van algemeen-ecologische crisis niet noodzakelijk tot de eerste vorm van intern-economische crisis leidt. Zolang het kapitalisme arbeidskrachten en grondstoffen (welke ook) kan vinden, kan het voorlopig verder. Het kapitalisme kan lange tijd verder bestaan, ondanks de toenemende milieuschade die het veroorzaakt. Vandaar het fenomeen dat we vandaag zien: hoewel de mondiale ecologische voetafdruk zo'n $120 \%$ bedraagt van de beschikbare biofysische capaciteit van de aarde, lijkt het kapitalistische mechanisme krachtiger dan ooit. Als het systeem door de milieucrisis ooit 
diepgaand verstoord geraakt, zal het wellicht te laat zijn. Bewuste strijd om het zover niet te laten komen, is dan ook van wezensbelang.

\section{Naar een ecosocialisme?}

$\mathrm{Nu}$ het neoliberalisme de sociale rechten waarvoor de arbeidersbeweging heeft gestreden, onderuit haalt, en na de verschrikkingen van het stalinisme, is het linkse project meer dan ooit in crisis. Tegelijk is de nood an een alternatief voor de huidige economische accumulatiemachine groter dan ooit. In plaats van de condities van een 'hogere' maatschappijvorm te creëren, ondermijnt het kapitalisme vandaag de basis voor een duurzame, egalitaire maatschappij. Het zadelt elk postkapitalistisch maatschappijproject op met een loodzware ecologische erfenis, maar ook met technologieën, levenswijzen en instituties die niet de basis kunnen zijn voor een andere, duurzame maatschappij.

Vandaar de noodzaak om nog radicaler te zijn, nog meer naar de wortels te gaan. Om de diepgaande verstoring van het metabolisme te herstellen, volstaat het niet om de eigendomsverhoudingen te veranderen en democratische controle in te voeren op het economische gebeuren. Er moet veel dieper ingegrepen worden in de erfenis die het kapitalisme ons nalaat.

Ten eerste zal een postkapitalistisch project grote delen van het huidige productieapparaat moeten ontmantelen en vervangen, net zoals de arbeiders tijdens de Parijse Commune in 1871 het gecentraliseerde staatsapparaat vernietigden om het te vervangen door een gedecentraliseerd model dat meer democratische participatie mogelijk maakt. Een simpele verandering van de eigendomsverhoudingen, zelfs in de meest democratische zin, kan niet meer volstaan. Dat is eigenlijk het uitgangspunt van de discussie over ecosocialisme. ${ }^{29}$ Sectoren zoals de automobielproductie of de gecentraliseerde productie van energie op basis van fossiele brandstoffen of van kernenergie moeten eigenlijk ontmanteld worden en vervangen door iets anders (openbaar vervoer, een gedecentraliseerd stelsel van hernieuwbare energie enzovoort). Ze zijn vandaag echter in privéhanden en vormen een enorme macht, zodat de gemeenschap er nauwelijks een vinger naar kan uitsteken. Vandaag beschikken we niet over de instituties om een breed maatschappelijk debat te voeren over welke vormen van productie we wel en niet wensen. De verwerving van dergelijke democratische controle is dan ook een voorwaarde om deze sectoren planmatig te kunnen omvormen en beheren. Elementen van centrale planning hoeven overigens geen belemmering te zijn voor een verregaand gedecentraliseerd stelsel van zelfbeheer in de productie-eenheden, waar de onmiddellijke producenten, consumentenbewegingen en lokale gemeenschappen dit beheer waarnemen. Op basis van een democratisch proces kan bijvoorbeeld centraal beslist worden de automobielsector te ontmantelen en te vervangen door productie van treinstellen, 
terwijl de uitvoering van deze optie zoveel als mogelijk gedecentraliseerd verloopt.

Een dergelijk democratisch beslissingsproces moet natuurlijk mee gestuurd worden door een sterk ecologisch bewustzijn. Er is dan ook in tweede instantie een fundamentele cultuurrevolutie nodig die komaf maakt met de kwantitatieve geld- en bezitslogica. Een dergelijke bewustzijnsrevolutie zal des te meer nodig zijn, in de mate individuen ook vrijwillig afstand moeten nemen van een aantal schadelijke praktijken, zoals de overmatige vleesconsumptie. Ze moet bijdragen aan een maatschappijmodel waar niet enkel minder, maar vooral ook anders geproduceerd en geconsumeerd wordt, aan een 'morele economie', die gebaseerd is op niet-monetaire en extraeconomische criteria. ${ }^{30}$

Ten derde is het herstel en de uitbreiding van de commons een cruciale opgave. In een 'communisme van de commons moeten zoveel mogelijk publieke goederen aan private en aan bureaucratische overheidshanden worden onttrokken, om ze lokaal, gedecentraliseerd en democratisch te beheren. Democratische controle op een heleboel terreinen veronderstelt in het algemeen overigens een radicale uitbreiding van de openbare sfeer (openbare diensten, commons, democratische instituties...), en een toename van de tijd die mensen ter beschikking hebben om hierin te participeren. Een scherpe arbeidsduurvermindering draagt hiertoe bij. Deze aloude syndicale eis heeft overigens een belangrijke ecologische dimensie. Het kapitalistische antwoord op de stijging van de arbeidsproductiviteit bestaat erin meer te produceren in dezelfde arbeidstijd. De sociaal-ecologische strategie van het 'genoeg' bestaat er daarentegen in op te houden met produceren van zodra de reële behoeften bevredigd zijn. De tijd die vrij komt, kan dan ingezet worden voor participatie in het democratisch zelfbeheer (dat tijdsintensiever is dan autoritaire beslissingsprocedures) en voor culturele, artistieke of andere sociale bezigheden, die minder druk leggen op het ecosysteem dan de zogenaamde vrijetijdsbestedingen in de huidige consumptiemaatschappij. Vrije tijd moet opnieuw bevrijde tijd kunnen worden!

Een dergelijke maatschappij zal ten vierde moeten trachten zoveel mogelijk vormen van maatschappelijke arbeidsdeling op te heffen: die tussen de maatschappelijke klassen, tussen manuele en intellectuele arbeid, en tussen stad en platteland (en bij uitbreiding tussen noord en zuid). Dat veronderstelt o.a. een reductie van de schaal (bijvoorbeeld herstel van kleinschalige biolandbouw) en de radicale herlokalisering van productie en consumptie, tegen het huidige absurde wereldhandelssysteem in.

Deze discussie staat uiteraard nog in zijn kinderschoenen. Het gaat er overigens niet om een soort utopie te bedenken, maar wel een aantal reële sporen te ontwikkelen om de milieucrisis te lijf te gaan. In een democratische ecosocialistische maatschappij zullen uiteraard niet alle problemen in een handomdraai opgelost zijn, en zullen diepe conflicten over beleidskeuzes blijven 
bestaan. Maar in elk geval kunnen de instrumenten die nodig zijn om de aarde te redden op die manier wel in de handen van de gemeenschap komen.

De moeilijkste vraag, waarover nog maar weinig literatuur bestaat, is uiteraard de strategische: hoe de milieubeweging verbinden met de arbeidersbeweging, en het klassenbewustzijn bevruchten met het milieubewustzijn? Deze vraag kan uiteraard enkel doorheen de collectieve praktijk en discussie worden beantwoord. Dat de arbeidersbeweging door het neoliberalisme in een defensieve strijd voor het behoud van de werkgelegenheid is geduwd, maakt het er uiteraard niet makkelijker op. Cruciaal is de ecologische en de sociale kwestie te verbinden: dat is de enige manier waarop een strategie van radicale maatschappijverandering ook een sociale meerderheid kan vinden, en massa's mensen actief kan betrekken in een veranderingsproces. Het gaat erom een programma en een praktijk te vinden die sociale herverdeling, democratisering en milieu systematisch verbinden. Dus geen lineaire prijsverhogingen bijvoorbeeld, maar publieke oplossingen. Dat kan gaan van het opzetten van nieuwe openbare diensten voor de isolatie van huizen en de publieke investeringen in hernieuwbare energie of openbaar vervoer tot de reconversie van pakweg de automobielindustrie in de productie van trein- of tramstellen, met behoud van tewerkstelling.

Er zijn natuurlijk een aantal aanknopingspunten in het heden waarrond een collectieve praktijk kan worden ontwikkeld: arbeiderscontrole rond milieuaspecten van het productieproces, de strijd voor de openbare diensten en voor het redden van de commons, arbeidsduurvermindering als eis van het 'genoeg'... Elke kleine overwinning op een dergelijk terrein geeft zelfvertrouwen, vergroot het sociaal-ecologisch bewustzijn, toont aan dat het mogelijk is iets te veranderen, en is een opstapje naar meer. In het marxisme wordt dit een overgangsbenadering genoemd, waarin getracht wordt elke kleine overwinning de basis te laten zijn van een hoger bewustzijn en een verdere eis. Rond de meeste van deze kwesties moet het debat en het experiment in de praktijk echter nog grotendeels beginnen. Een proces dat gebaat is met de grootst mogelijke openheid en eenheid in actie binnen de linkerzijde.

\section{Noten}

1 Dit artikel verscheen eerder in Oikos 46, 3/2008.

2 Tanuro D., Marx's concept of social metabolism and ecosocialist responses to climate change. Speech at the event 'Ecosocialism or Barbarism', Socialist Resistance, Londen, 2 december 2006.

3 Derrida J., Spectres de Marx. L'étal de la dette, le travail du deuil et la nouvelle Internationale, Parijs, Galilé, 1993.

4 Bijvoorbeeld de Franse auteur Michael Löwy. 
5 Foster J.B., Marx's Ecology. Materialism and Nature. New York, Monthly Review Press, 2000.

6 Marx K., Hel Kapitaal I, De Haan, Bussum, 1974, p. 386.

7 Marx K., Capital, Vol. III, Moskou, Progress Publishers, 1978, p. 813. cfr. Marx K., Het Kapitaal, p. 121.

8 Marx K., Het Kapitaal, p. 386.

9 Foster J.B., Marx's Ecology, p. 158.

10 Ibid., p. 156.

11 Geciteerd in Foster J.B., p. 159.

12 Marx K., Capital, Vol. III, p. 776.

13 Marx K., Grundrisse, Penguin Books, 1977, p. 489.

14 Burkett P., Marxism and Ecological Economics. Towards a Red and Green Political Economy, Leiden, Brill, 2006, p. 84.

15 Marx K., Economisch-filosofische manuscripten, 1844, Moskou, Uitgeverij Progres, 1987.

I6 Cfr. Altvater E., Is there an Ecological Marxism? Lecture at the Virtual University of CLACSO - Consejo Latinoamericano de las ciencias sociales, 2003.

17 cfr. Mandel E., Het Laatkapitalisme. Proeve van een marxistische verklaring, Amsterdam, Van Gennep, 1976.

18 In zijn Kritiek op het Programma van Gotha bekritiseert Marx de Duitse Arbeiderspartij die in haar programma stelde dat arbeid de bron van rijkdom is. De natuur is dat volgens Marx evenzeer, en de arbeid is eigenlijk zelf een natuurkracht. Marx K., Kritiek op het Programma van Gotha, Amsterdam, Uitgeverij Pegasus, 1978, p. 17.

19 "Het historisch materialisme presenteert zichzelf precies als een-benadering voor de studie van menselijke maatschappijen, (...) als (...) ecologie toegepast op menselijke populaties." Benton T., 'Marxism and Natural Limits: An Ecological Critique and Reconstruction', in: New Left Review, I/178, Nov-Dec 1989, pp. 51-86.

20 Karl Kautsky in 'La Question Agraire', Paris (1900). Geciteerd in Tanuro, D., 'Energie de flux ou énergies de stock? - Un cheval de Troie dans l'écologie de Marx', in : [Europe Solidaire Sans Frontières], http://www.europe-solidaire.org/spip.php?article8382. 21 De logica van de private toe-eigening van de grond leidt volgens Marx tot het privilege om "het binnenste van de aarde, de lucht en daarmee het behoud en de ontwikkeling van het leven" zelf te exploiteren. Marx K., Capital, Vol. III, p. 774.

22 De bevrijding van 'groene' productiekrachten van het kapitalistische keurslijf is broodnoodzakelijk om het milieu te redden. Zie hiervoor : Tanuro D., Marx, Mandel et les limites naturelles, in : [Europe Solidaire Sans Frontières] - http://www.europesolidaire.org/spip.php?article2475.

23 Tanuro D., Energie de flux ou énergies de stock? - Un cheval de Troie dans l'écologie de Marx.

24 Er zijn twee voorwaarden opdat een rente kan worden opgestreken. Ten eerste is een rente maar mogelijk wanneer er natuurlijke limieten zijn. Op zonne-energie is er geen dergelijke rente te verwerven, hoewel er natuurlijk winst is te maken met de verkoop van zonnepanelen. Ten tweede moet er sprake zijn van een vorm van private toe-eigening, en dus van monopolie van bezit binnen een kleine groep. Vandaar het sterk gecentraliseerde (en inefficiënte) karakter van het huidige energiesysteem: de decentralisering van de energieopwekking (ieder haar windmolen of zonnepanelen op haar dak) zou een dergelijk monopolie, en dus de rente, onmogelijk maken. De keuze voor het huidige, 
gecentraliseerde energiesysteem is dan ook geen toevallige of neutrale kwestie, maar past in de logica van het kapitalisme. Merk trouwens op dat het fotovoltaïsch effect al in 1839 was ontdekt, en dat eind $19^{\text {de }}$ eeuw technieken beschikbaar waren op basis van zonnewarmte. De keuze voor bepaalde technologieën ten koste van andere, is altijd een sociaal-politieke keuze. Technologie is niet neutraal.

25 Tanuro D., Energie fossiles, climat et anticapitalisme, in : [Europe Solidaire Sans Frontières], http://www.europe-solidaire.org/spip.php?article5568). Te vergelijken met het bedrag dat in het Sternrapport naar voor wordt geschoven om de temperatuurstijging door de klimaatsverandering te beperken tot maximaal $2^{\circ} \mathrm{C}$ : tussen de 1050 en 1200 miljard dollar per jaar.

26 Voor een goeie inleiding op dit debat: zie hiervoor: Jones P.T., Globaal ten Onder? Pleidooi voor een Ecologische Economie, Discussiecahier van de Wetenschappelijke Raad van Attac-Vlaanderen, 2006; en Jones P.T. \& Jacobs R., Terra Incognita. Globalisering, ecologie en rechtvaardige duurzaamheid, Gent, Academia Press, 2006.

27 Zie hiervoor Altvater E., 'The social and natural environment of fossil capitalism', in: The Socialist Register 2007: coming to terms with nature, Panitch L. \& Leys C. (red.), Monmouth, The Merlin Press, 2006, pp. 37-59.

28 Burkett P., Marxism and Ecological Economics, p. 136.

29 Zie hiervoor: Löwy M., 'Eco-socialism and democratic planning', in: The Socialist Register 2007: coming to terms with nature, Panitch L. \& Leys C. (red.), Monmouth, The Merlin Press, 2006, pp. 294-309.; Löwy M., (coord.), Ecologie et socialisme, Paris, Syllepse, 2005.

30 Löwy M., 'What is ecosocialism', in: Ecosocialism or Barbarism, Socialist Resistance books, Kelly J. \& Malone S. (red.), Londen, 2006, p. 6. 